\title{
Restoration of pro-inflammatory cytokines and histopathological changes in pancreas and liver of hyperglycemic rats by Murraya koenigii leaves extract
}

\author{
Fauzul Husna ${ }^{1}$, Franciscus D. Suyatna ${ }^{2 *}$, Wawaimuli Arozal ${ }^{2}$, Erni H. Purwaningsih ${ }^{3}$, Yulvian Sani ${ }^{4}$ \\ ${ }^{1}$ Department of Pharmacology, Faculty of Medicine, Universitas Syiah Kuala, Aceh, Indonesia. \\ ${ }^{2}$ Department of Pharmacology, Faculty of Medicine, Universitas Indonesia, Jakarta, Indonesia. \\ ${ }^{3}$ Department of Pharmacy, Faculty of Medicine, Universitas Indonesia, Jakarta, Indonesia. \\ ${ }^{4}$ Indonesia Research Center for Veterinary Sciences, Ministry of Agriculture, Bogor, Indonesia.
}

\begin{tabular}{|c|c|}
\hline ARTICLE INFO & ABSTRACT \\
\hline $\begin{array}{l}\text { Received on: } 13 / 05 / 2019 \\
\text { Accepted on: } 29 / 09 / 2019 \\
\text { Available online: } 03 / 01 / 2020\end{array}$ & $\begin{array}{l}\text { This study aims to investigate whether the characteristic of anti-inflammatory and protective effect of hepato- pancreas } \\
\text { could mediate the antihyperglycemic effect of Murraya koenigii. Twenty-five Sprague-Dawley rats were induced } \\
\text { hyperglycemia by streptozotocin and nicotinamide (STZ-NA). The hyperglycemic rats were treated with an ethanolic } \\
\text { extract of } M \text {. koenigii } 200 \mathrm{mg} / \mathrm{kg} \mathrm{b.w} \mathrm{and} 400 \mathrm{mg} / \mathrm{kg} \text { b.w. One group of the rats was treated with glibenclamide }(1 \mathrm{mg} /\end{array}$ \\
\hline $\begin{array}{l}\text { Key words: } \\
\text { Anti-inflammatory, } \\
\text { histomorphological, } \\
\text { hyperglycemia, } \\
\text { Murraya koenigii. }\end{array}$ & $\begin{array}{l}\mathrm{kg} \text { b.w). After } M \text {. koenigii extract and glibenclamide for } 4 \text { weeks, the rats were sacrificed. Blood and organ samples } \\
\text { were collected under a fasting condition. The evaluation was made towards the expression of pro-inflammatory } \\
\text { cytokines (TNF- } \alpha \text {, IL-1 } \beta \text { ) as well as the histopathological change in the liver and pancreas. The beneficial effects of } \\
\text { Murraya ko enigii would bring the anti-inflammatory and hepatoprotective effect and increased the number and size } \\
\text { of islet Langerhans. This research reveals that } M \text {. koenigii has a charateristic of anti-inflammatory, hepatoprotective, } \\
\text { and it contributes to regeneration of damaged pancreatic islet. This effect is accompanied by a decrease in plasma } \\
\text { glucose levels. }\end{array}$ \\
\hline
\end{tabular}

\section{INTRODUCTION}

Diabetes mellitus (DM) is a metabolic disturbance characterized by hyperglycemia which is the principal clinical manifestation in consequence of deviation in insulin secretion, insulin action, or both (Stumvoll et al., 2005). In 2015, around 415 million people were diagnosed with diabetes, in which more than $90 \%$ of them had type 2 diabetes. This figure is likely to increase with a projection of 642 million by 2040 (IDF, 2015). Between 1980 and 2004, the global rise in obesity, sedentary lifestyles, and an aging population has quadrupled the incidence and prevalence of type 2 diabetes (Chatterjee et al., 2017). The incidence and prevalence of type 2 diabetes vary according to geographical region, with more

\footnotetext{
${ }^{*}$ Corresponding Author

Franciscus D. Suyatna, Department of Pharmacology,

Faculty of Medicine, Universitas Indonesia, Jakarta, Indonesia.

E-mail:fransdsuyatna@yahoo.com,franciscus.suyatna@ui.ac.id
}

than $80 \%$ of patients living in low-to-middle-income countries. Nonetheless, the overall trend is increasing in diabetes prevalence in every country since 1980 (Risk and Collaboration, 2016).

The type 2 diabetes is characterized by relative insulin deficiency which is caused by pancreatic $\beta$-cell dysfunction as well as insulin resistance in target organs. Type 2 diabetes is characterized by hyperinsulinemia, insulin resistance, and pancreatic $\beta$-cell failure, with up to $50 \%$ cell loss at diagnosis (Holman et al., 2008). Likewise, the organs involved in type 2 diabetes development are pancreas ( $\beta$ cells and $\alpha$ cells), liver, skeletal muscle, kidney, brain, small intestine, and adipose tissue (Defronzo, 2009). The abnormality in structure and function of pancreatic $\beta$ cells induces a decrease in insulin secretion progressively. This condition brings negative impacts on the role of insulin target organs, in particular, on the liver, which is an organ that plays in glucose homeostasis through the regulation of glycolysis, glycogenesis, and gluconeogenesis (Lin and Accili, 2011; Moore et al., 2012). On a related matter, chronic hyperglycemia could 
interfere the function and structure of the liver as a consequence in adapting the pathological condition (Majaw et al., 2018). Some of the organ systems are contributing towards pathogenesis and complication of diabetes. Another study also reported that the disruption of pancreas and liver structure could increase blood glucose level dysregulation in the body (Kahn et al., 2014).

Hyperglycemia plays a role in the formation of reactive oxygen species (ROS) through four classic pathways: increase in the polyol pathway; increase in Advanced glycation end productreceptor advanced glycation end product (AGE-RAGE) formation; protein kinase $\mathrm{C}(\mathrm{PKC})-\mathrm{NFKB}$ activation; and increase in the hexosaminase pathway. These contribute to causing oxidative stress in various organs, which is the main pathway to the disorder in DM triggering complications of various microvascular and macrovascular organs. In line with this, inflammation is closely related to the pathogenesis of T2DM, where various clinical, preclinical, and epidemiological studies have shown the link of the development of DM and its complications with oxidative stress and inflammatory stress (Fernández-Real \& Pickup, 2008; Kalupahana et al., 2012)

In addition, free radicals produced in the DM state will trigger oxidative stress and affect various signaling pathways. As a consequence, the process will bring an impact in cell metabolism and triggers low-level inflammatory reactions through the activation of nuclear factor kappa-B $(\mathrm{NF}-\kappa \mathrm{B})$ in which will stimulate the production and secretion of cytokines and proinflammatory chemokines. The activation of these pathways would increase the production and release of pro-inflammatory cytokines and related to the inflammation condition. In line with this, cytokines induce cellular damaged directly through inhibition of Suppressor of cytokine signaling (SOCS)3 or through the activation kinases. This condition will interfere cascade signal of insulin (Pickup, 2004). Therapeutic diabetes will be potentially targeting three conditions of the organs: the protective mechanism, management of free radical production, and an inflammation condition (Ibrahim et al., 2018; Rajendiran et al., 2018).

Since inflammation is related closely to diabetes, a plant with anti-inflammatory characteristic may have beneficial effects for improving hyperglycemia. Furthermore, that sort of plant is great to be used in therapy, which plays as an adjunctive agent for diabetic condition and is capable for the development of antihyperglycemic drugs (Bhat et al., 2019; Kavishankar and Lakshmidevi, 2014).

Indonesia is the world's second-largest country with abundant natural resources, which is driven for developing its native plants for wide use in the health industry including to cope with diabetes. Empirical evidence of the wide use of herbal medicine has become a strength of the country to develop its traditional medicinal plants. According to data from Indonesia's basic health research in 2013, there were $30.4 \%$ of Indonesian's population tend to use traditional health services, with about $49 \%$ of them dealing with herbs for their health treatment (Riskesdas, 2013). This means that traditional medicine has taken a big portion in Indonesian's health sector. Nevertheless, plant-derived agents used for treatment must have been scientifically proved in order to measure the side effects and efficacy. Various plants used by Indonesian people and have adequate scientific evidence to deal with diabetes are Momordica charantia, Cinnamomum burmanni, Nigella sativa, and Andrographis paniculata (Kementerian
Kesehatan RI, 2011). Adding to the list, people in recent years also make use of Murraya koenigii to treat diabetes traditionally.

Murraya koenigii, also known as curry leaves, is widely distributed in the tropical and sub-tropical continent of South-East Asia and India (Handral et al., 2012). In Indonesia, M. koenigii is regularly used as spice and flavor enhancer in food processing. In the Ayurvedic system, M. koenigii is traditionally used to resolve stomachache, diarrhea, headache, insect bites, influenza, itching, and dysentery. Some of the scientific reports have revealed the beneficial of M. koenigiias an anticancer (Samanta et al., 2018), antioxidant (Ningappa et al., 2008), hypolipidemic (Birari et al., 2010), and antihyperglycemic (Kesari et al., 2005; Kesari et al., 2007). In this study, we would investigate the anti-inflammation and protective effect on the liver and pancreas of normal and hyperglycemic rats that administrated M. koenigii extract (MKE).

\section{MATERIALS AND METHODS}

\section{Chemicals and animal}

All procedures of using live animals in this study have been approved by the Ethics Committee of the Faculty of Medicine, Universitas Indonesia (letter-number 643/UN2. F1/ETIK/2015). The NIH Guide for Care and Use of Laboratory Animals was used as the standard guidelines of any appliances applied in this study. Male Sprague-Dawley rats weighing of 170-250 g were purchased from the Animal Centre of The Board of Health Research and Development Indonesia (Jakarta, Indonesia). They were inducted hyperglycemia with streptozotocin and nicotinamide. All chemicals and reagents used in the study were considered as analytical grades.

\section{Preparation of extract}

After the confirmation by a taxonomist from the Indonesia Institute of Sciences (LIPI), Indonesia, on the identity of the curry tree, we derived its mature leaves from Aceh, Indonesia, in July 2015. Dried at room temperature for 14 days, $1 \mathrm{~kg}$ of the leaves was grounded to coarse powdered using an electric grinder. The powder was macerated in ethanol $96 \%$ with intermittent shaking. The extract was filtered and concentrated under reduced pressure and a rotary evaporator at $50^{\circ} \mathrm{C}$ and stored at $4^{\circ} \mathrm{C}$ for its use in the future.

\section{Induction of DM}

Hyperglycemia was induced by injection of STZ intraperitoneally $(55 \mathrm{mg} / \mathrm{kg})$ and dissolved in $0.1 \mathrm{M}$ cold citrate buffer $(\mathrm{pH} 4.5), 15$ minutes after the administration of intraperitoneal nicotinamide at $120 \mathrm{mg} / \mathrm{kg}$. After 3 days, the level of fasting plasma glucose (FPG) was measured from the tail vein using an Accu-Chek Performa glucometer (Roche Diagnostics Ltd. Co.Germany). The rats with FPG $\geq 250 \mathrm{mg} / \mathrm{dl}$ were considered diabetic and included in the study. The report of this parameter was previously reported (Husna et al., 2018).

\section{Experimental design}

The experiment was carried out towards five groups, composing of five rats in each group. All treated with test/standards for 30 days with the following protocols:

Group 1: Normal rats, treated with $0.5 \%$ carboxymethyl cellulose (CMC-NA) solution control (CON); Group 2: Diabetic 
rats, treated with $0.5 \%$ CMC-NA solution (DM); Group 3: Diabetic rats, treated with $200 \mathrm{mg} / \mathrm{kg}$ MKE (DM+L); Group 4: Diabetic rats, treated with $400 \mathrm{mg} / \mathrm{kg}$ MKE (DM+H); and Group 5: Diabetic rats, treated with $1 \mathrm{mg} / \mathrm{kg}$ glibenclamide (DM+GLI).

MKE and glibenclamide suspensions, prepared by dispersion in $0.8 \%$ natrium- CMC-NA, were administered orally via feeding canula once a day. During the experimental period, the body weight and FPG of all rats were monitored weekly.

\section{Collection of tissues}

On the 30th day, the rats were sacrificed through cervical decapitation. The liver and pancreas tissues were excised, rinsed in ice-cold normal saline, dried individually on clean filter paper, and weighed. Some parts of the liver was placed in sterile and nuclease-free Eppendorf and stored at $-80^{\circ} \mathrm{C}$, while the other parts of the liver and pancreas were used for the histological study.

\section{Determination of relative expression of pro-inflammatory cytokines level in hepatic hyperglycemia rats}

The liver was applied to estimate pro-inflammatory cytokine levels. Total RNA was extracted from liver tissues of each rats using High Pure RNA tissue kit reagent (Roche, USA), first-strand cDNA was synthesized with Transcriptor First Strand cDNA Synthesis kit (Roche, USA) using $1 \mu \mathrm{g}$ total RNA.

tumor necrosis factor- $\alpha(\mathrm{TNF}-\alpha)$ and interleukin- $1 \beta$ (IL-1 $\beta$ ) gene expression were determined by quantitative realtime polymerase chain reaction (PCR) analysis that performed with FastStart Essential DNA Green Master (Roche, USA) in LightCycler ${ }^{\circledR}$ Nano software system $\left(\right.$ Roche $\left.^{\circledR}\right)$. were used:

The following gene-specific oligonucleotide primers

Primer for rat TNF- $\alpha$ is 5 '-TCT ACT ACC AGG TTC TCT TCA-3' (forward) and 5'-CTC CTG GTA TGA AAT GGC AAA TC-3' (reverse)

Primer for rat IL-1 $\beta$ is $5^{\prime}$-CTCCATGAGCTTTGTACAAGG-3' (forward ) and 5'-TGC TGA TGT ACC AGT TGG GG-3'(reverse)

Primer for rat $\beta$-actin is $5^{\prime}$-GGC ATC GTG ATG GAC TCC G-3' (forward) and 5'-GCT GGA AGG TGG ACA GCG A-3' (reverse)

Cycling conditions were $42^{\circ} \mathrm{C}$ for 5 minutes; $95^{\circ} \mathrm{C}$ for 5 minutes and 45 cycles of $95^{\circ} \mathrm{C}$ for 15 seconds; $60^{\circ} \mathrm{C}$ for 30 seconds and $72^{\circ} \mathrm{C}$ for 30 sesonds. The relative amount of these mRNA was normalized to the amount of endogenous control, $\beta$-actin, analyzed melting curves, and the $\Delta \Delta \mathrm{Ct}$ method.

\section{Pancreas histopathological study}

Following the sacrifice, the pancreas was removed from the dead rats and blotted on filter paper. To assess the histology and morphology of pancreatic islet in the rat, its pancreas tissue was fixed in $10 \%$ buffered formalin phosphate and embedded in paraffin. After that, it was prepared as $5-\mu \mathrm{m}$-thick section and was stained with hematoxylin and eosin $(\mathrm{H} / \mathrm{E})$. The number and size of islet were measured and counted in 5-fields of each $\mathrm{H} / \mathrm{E}$ stained slide under the light of microscope (Leica DM 1000 LED, $\times 40$ and $\times 100$ ). Then the proportion of $\beta$ and $\alpha$ cells in five islets Langerhans were counted $(\times 200)$. The measurement of these parameter was done using the ImageRaster3 software.

\section{Liver histopathological study}

Similar to the pancreas treatment, to asses the histological examination of the liver, a part of the liver was rinsed with normal saline and fixed in $10 \%$ buffered formalin phosphate. It was embedded in paraffin and cut as 5 - $\mu$ m-thick section, before stained with hematoxylin and eosin $(\mathrm{H} / \mathrm{E})$, the procedure and examination was done under the light of microscope. The changes associated with histopathological, hydropic degeneration, vesicular vacuoles, sinusoidal congestion, and cell necrosis in the liver were scored in 10 fields of each $\mathrm{H} / \mathrm{E}$-stained slide and examined under the light of microscope (Leica DM 1000 LED, ×40). The histopathological findings were marked as none $(0)$, mild $(+)$, moderate $(++)$, and severe damage $(+++)$ (Desmet, 2003).

\section{Statistical analysis}

All data were presented as mean \pm SEM, with statistical analysis was undertaken by one-way ANOVA followed by least significant difference (LSD) pos hoc using SPSS version 20. Any values of $p<0.05$ were considered statistically significant.

\section{RESULTS}

Effect of MKE on pro-inflammatory cytokine levels in hyperglycemic rats

The untreated hyperglycemic rats shown a significant increase in the levels of pro-inflammatory cytokines TNF- $\alpha$ and IL$1 \beta$ in the liver compared to the control/normal rats (Fig. 1a and b). On the other hand, hyperglycemic rats that were applied MKE at dose 200 and $400 \mathrm{mg} / \mathrm{kg}$.bw for 30 days resulted a significant decrease in the regulation of TNF- $\alpha$ and IL- $1 \beta$ in their liver.

\section{Effect of MKE on histology and histomorphologic changes in pancreas of hyperglycemic rats}

The results of histology and histomorphological examinations of the pancreas are shown in Figures 2 and 3. It stated that the relative reduction of size and number of islet were detected in hyperglycemic rats. Similarly, MKE-treated hyperglycemic rats showed clearly the restoration in the size and number of islets.

\section{Effect of MKE on histology and histomorphologic changes in liver of hyperglycemic rats}

This study supports the hepatoprotective effect of $M$. koenigii extract on the liver damage of rats that induced by hyperglycemia (Table 1). The results of histopathological examinations of the liver are shown in Figure 4.

\section{DISCUSSION AND CONCLUSION}

This research aims at investigating the effect of MKE in hyperglycemic rat as well as to explore the anti-inflammatory effects and protective effect in the pancreas and liver of hyperglycemic rats, which administrated with curry leaves extract. This was done to establish pharmacological evidence and scientific support of the use of $M$. koenigii in the treatment of DM. The findings show that the characteristic of anti-inflammation is mediated by the antihyperglycemic action of MKE in hyperglycemic rats. What is more, MKE could preserve the morphology of the liver and pancreas of hyperglycemic rats. We also used glibenclamide, a hypoglycemic drug, to compare the efficacy of the variety of antihyperglycemic compound in our extract. 
(A)

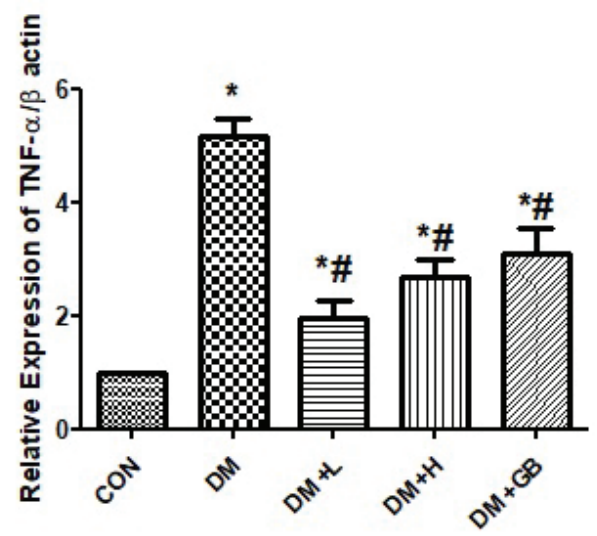

(B)

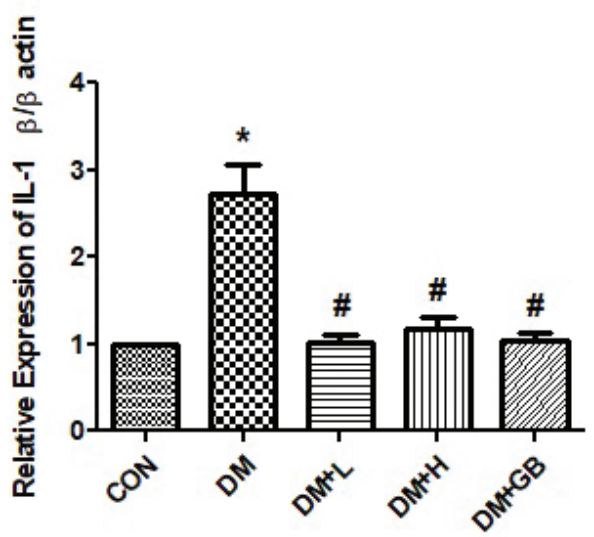

Figure 1. Effect of MKE on the expression of pro-inflammatory cytokines level, TNF- $\alpha$ (A), and IL-1 $\beta$ (B) in hepatic hyperglycemic rats. Values are presented as mean $\pm \operatorname{SEM}\left(n=5\right.$ for each group). ${ }^{*} p<0.05$ vs.CON group. ${ }^{\#} p<0.05$ vs $\mathrm{DM}$ group. $\mathrm{CON}=$ control, $\mathrm{DM}=$ Diabetic, $\mathrm{DM}+\mathrm{L}=$ diabetic with $M$. koenigii extract $200 \mathrm{mg} / \mathrm{kg}, \mathrm{DM}+\mathrm{H}=$ diabetic with $M$. koenigii extract $400 \mathrm{mg} / \mathrm{kg}, \mathrm{GB}=$ glibenclamide $1 \mathrm{mg} / \mathrm{kg}$.
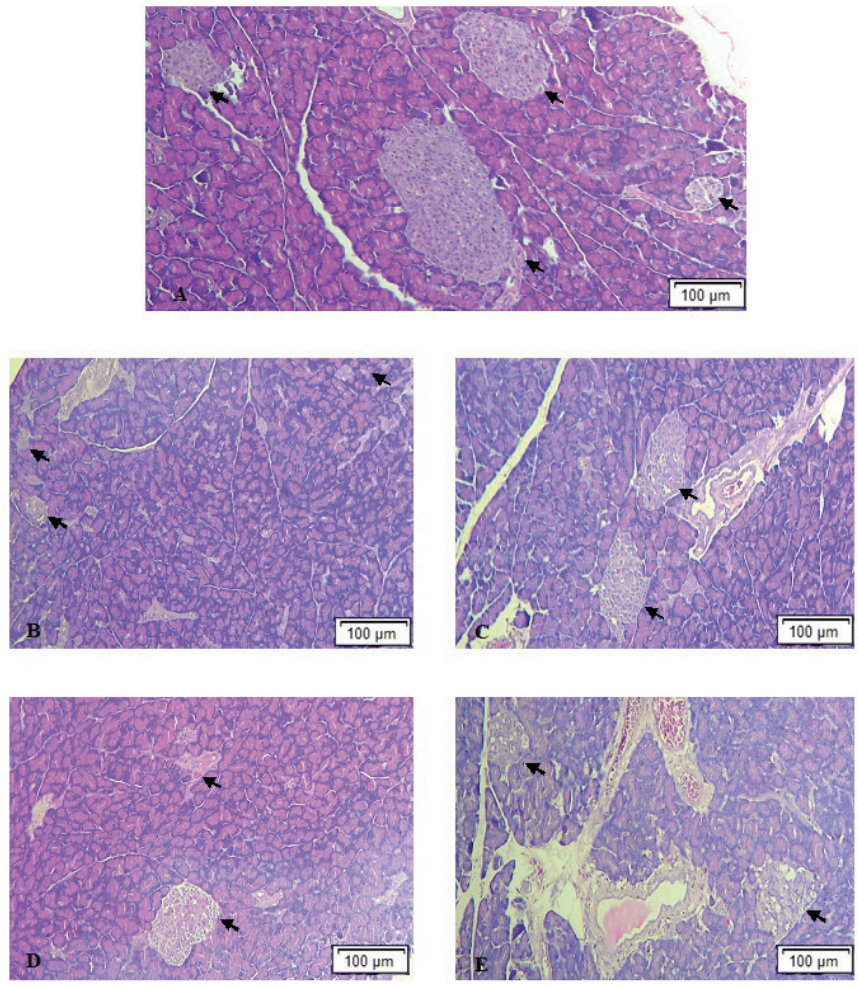

Figure 2. Light micrograph of pancreas of normal and hyperglycemic rats. (A) Normal, (B) Diabetic, (C) diabetic with M. koenigii extract200 mg/kg, (D) diabetic with $M$. koenigii extract $400 \mathrm{mg} / \mathrm{kg}$, (E) diabetic with glibenclamide $1 \mathrm{mg} / \mathrm{kg}$. Arrow = Islet Langerhans.

The majority of plants, particularly in Indonesia, with antihyperglycemic effects are now globally and widely used as a supplement therapy for diabetes. Thus, the research providing scientific evidence on the herbal medicine use needs to be developed intensively (Tahrani et al., 2011). Biological substances such asalkaloids, flavonoids, glycosides, and terpenoids that derived from the plants are often linked to antihyperglycemic effects (Grover et al., 2002). Our previous study of phytochemical screening of MKE revealed that flavonoids, steroids, and saponin are present qualitatively in our extract alongside 1.8-cineol, $\beta$-caryophyllene, hexadecene-1-ol, $\alpha$-matrine, benzo[a]naphtacene, 2H-3,5A-epoxynaphth[2,1-B]oxepin, 12-epilycodoline, $\gamma$-sitosterol, noruns-12-ene, and vitamin $\mathrm{E}$, which were identified by gas chromatography mass spectrometry (GC-MS) analyzer (Husna et al., 2018).

Diabetes mellitus is associated with structural and functional deformations in the $\beta$-cells of the pancreas. Insulin deficiency or resistance in target organs contribute to increasing blood glucose and affect the metabolism of carbohydrate, protein, and lipid (DeFronzo, 2004). Various clinical, preclinical, and epidemiological studies show that oxidative stress and inflammation are closely linked to the pathogenesis of DM and its complications. In addition, the production of free radicals in hyperglycemic condition would trigger oxidative stress and brings impact on various cellular signaling pathways. As a result, the cell metabolism is disturbed and the NF- $\kappa$ B pathway is activated. This condition poses lowlevel inflammatory reactions in which will stimulate the production and secretion of pro-inflammatory cytokines (Fernández-Real and Pickup, 2008; Kalupahana et al., 2012).

TNF- $\alpha$ is a pro-inflammatory cytokine that triggers secretion of other cytokines such as IL-6 and IL-1 $\beta$. Likewise, the role of pro-inflammatory cytokines in distrupting insulin signaling pathway could happen at various levels (Franckhauser et al., 2008). In their way through, the cytokines directly penetrate to phospholipid membrane, inhibit 5' adenosine monophosphateactivated protein kinase as well as affect the $\beta$-oxidation process leading to the activation of PKC pathway. While pro-inflammatory cytokines also trigger SOCS1,3 (Luis-Rodríguez, 2012), these kind of cytokines activate various signaling pathways such as nitric oxide (NO), protein phosphatase $2 \mathrm{~A}$, IкB kinase, and phosphoJun N-terminal kinase to inhibit phosphorylation of Akt protein. Both of these process interrupt insulin receptor substrate (IRS) and 
(A)

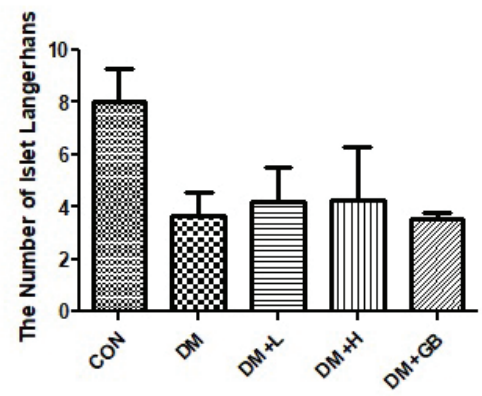

(B)

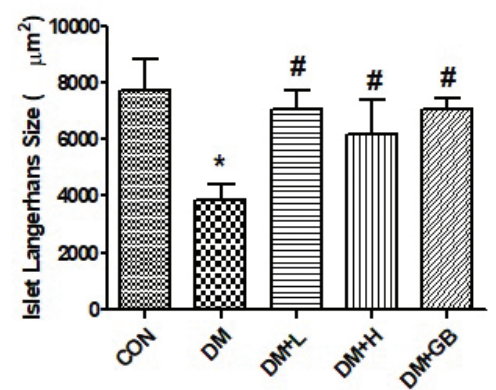

(C)

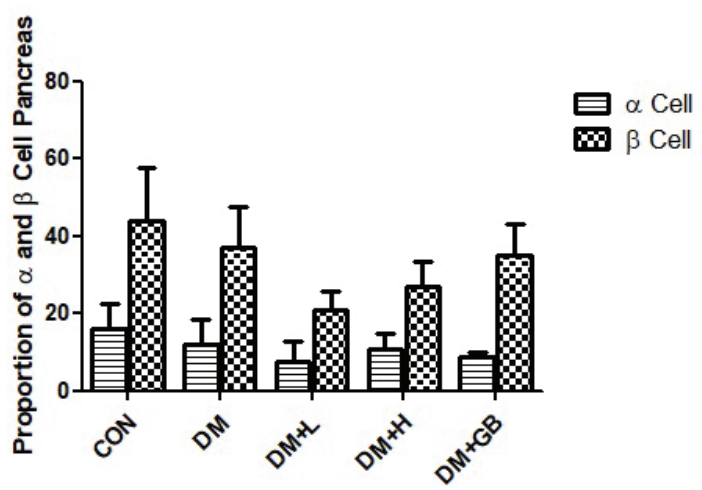

Figure 3. Effect of MKE on the number (A), size (B), and proportion cell $\alpha$ and $\beta$ (C) in Islet pancreas on hyperglycemic rats. Values are presented as mean $\pm \operatorname{SEM}\left(n=5\right.$ for each group). ${ }^{*} p<0.05$ vs. CON group. ${ }^{\#} p<0.05$ vs $\mathrm{DM}$ group. $\mathrm{CON}=$ control, $\mathrm{DM}=$ Diabetic, $\mathrm{DM}+\mathrm{L}=$ diabetic with $M$. koenigii extract $200 \mathrm{mg} / \mathrm{kg}, \mathrm{DM}+\mathrm{H}=$ diabetic with $M$. koenigii extract $400 \mathrm{mg} / \mathrm{kg}, \mathrm{GB}=$ glibenclamide $1 \mathrm{mg} / \mathrm{kg}$.

Table 1. Effect of MKE on histopathological changed in the liver hyperglycemic rats.

\begin{tabular}{lccccc}
\hline Groups & $\begin{array}{c}\text { Hydropic } \\
\text { degeneration }\end{array}$ & $\begin{array}{c}\text { Sinusoidal } \\
\text { congestion }\end{array}$ & Vacuoles & $\begin{array}{c}\text { Polymorpho } \\
\text { nuclear }\end{array}$ & $\begin{array}{c}\text { Cell } \\
\text { necrosis }\end{array}$ \\
\hline $\mathrm{C}$ & 0 & 0 & 0 & 0 & 0 \\
$\mathrm{DM}$ & + & ++ & ++ & ++ & + \\
$\mathrm{DM}+\mathrm{L}$ & + & + & 0 & + & 0 \\
$\mathrm{DM}+\mathrm{H}$ & + & + & + & + & + \\
$\mathrm{DM}+\mathrm{GB}$ & + & + & 0 & ++ & + \\
\hline
\end{tabular}

$\mathrm{CON}=$ control, $\mathrm{DM}=$ Diabetic, $\mathrm{DM}+\mathrm{L}=$ diabetic with $M$. koenigii extract $200 \mathrm{mg} / \mathrm{kg}, \mathrm{DM}+$ $\mathrm{H}=$ diabetic with $M$. koenigii extract $400 \mathrm{mg} / \mathrm{kg}, \mathrm{GB}=$ glibenclamide $1 \mathrm{mg} / \mathrm{kg}$.

$(0)$, mild $(+)$, moderate $(++)$, and severe damage $(+++)$.

influence the cascade signal of insulin that will eventually trigger insulin resistance in skeletal muscle and stimulate lipogenesis in the liver (de Luca and Olefsky, 2008; Kalupahana et al., 2012).

In this study, the relative expression of TNF- $\alpha$ and IL-1 $\beta$ mRNA increased in hyperglycemic rats. Due to the administration of MKE, TNF- $\alpha$ and IL-1 $\beta$ expression dropped to almost reach the normal level. This finding indicates that MKE has an effect in modulating the level of tissue inflammation caused by hyperglycemia, and improve insulin resistance in its target organs. In line with this study, Paul et al. (2011) reported the immunomodulating effect of $M$. koenigii extract by examining TNF- $\alpha$, IL 2, 4, and 10 expression in type 1 diabetes mellitus rats. Moreover,
Shah et al. (2008) also verified immuno-modulating activity of methanol extract curry leaves on humoral and cellular immune.

The metabolism of glucose is controlled through a feedback mechanism involving pancreatic $\beta$ cells and insulinsensitive tissues such as the liver, skeletal muscle, kidney, brain, small intestine, and adipose tissue. The sensitivity of such tissues to insulin influences the magnitude of the $\beta$ cell response. If insulin resistance occurs, the $\beta$ cells will maintain glucose tolerance by increasing insulin secretion. When $\beta$ cells are unable to compensate insulin resistance, on the other hand, the level of blood glucose will rise (Chatterjee et al., 2017).

The research showed that there was a reduction in the number and size of islet Langerhans in diabetic rats. Through the administration of MKE, the number and size of islet Langerhans in the rats were maintained to almost equivalent to the normal group. This study also analyzed the proportion and number of pancreatic $\alpha$ and $\beta$ cells to investigate the composition of cells involved in the secretion of the hormone insulin and glucagon. The results showed that there was no difference in the change proportion of pancreatic $\alpha$ and $\beta$ cells between the normal and diabetic rats. This is likely due to the degree of pancreatic damage in diabetic rat, which was not massive, so the pancreas was able to compensate the increasing in blood glucose level through increasing insulin secretion. The degree of pathological changes in experimental animals induced by streptozotocin and nicotinamide (STZ-NA) 

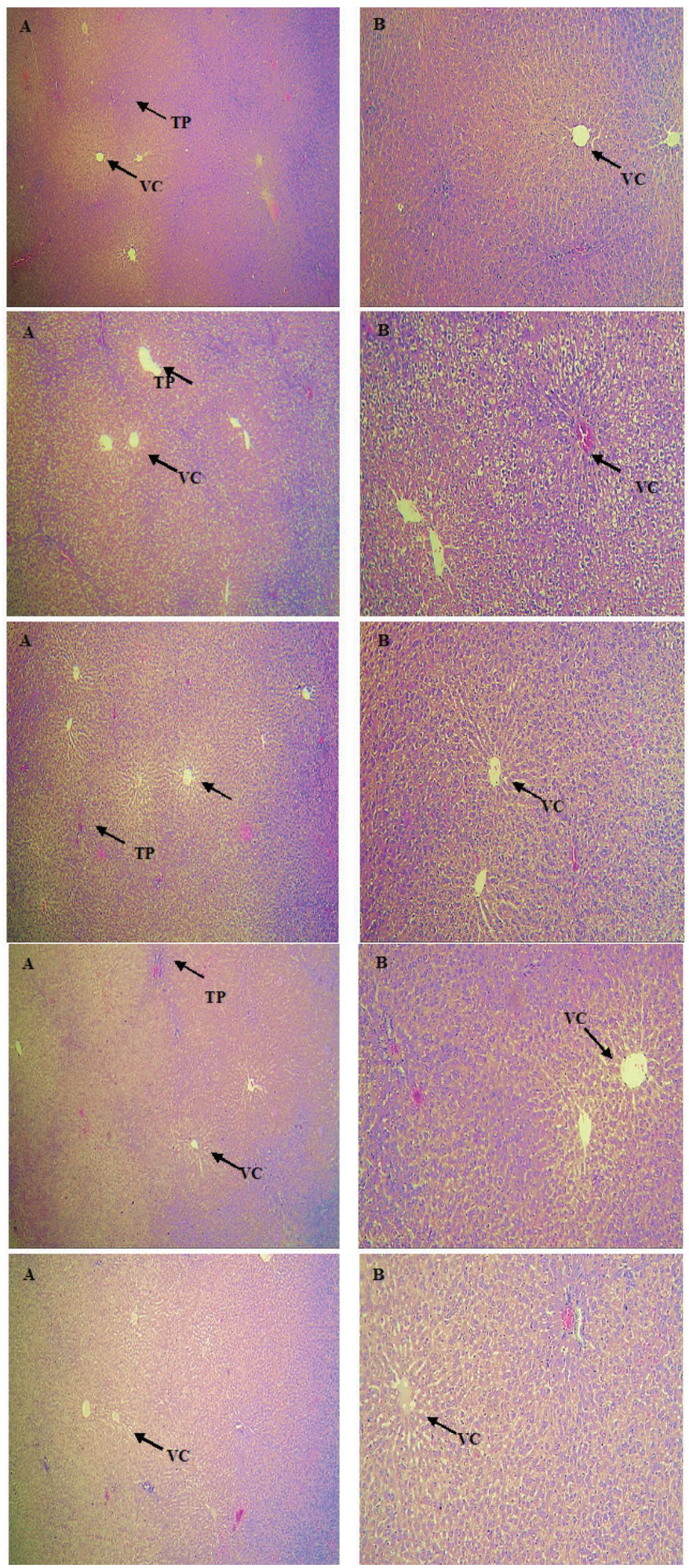

Figure 4. Effect of MKE on histology and histomorphologic changes in the liver of hyperglycemic rats. (A) $40 \times$, (B). $100 \times . \mathrm{VC}=\mathrm{V}$.Centralis, $\mathrm{TP}=$ Triad portal 1. $\mathrm{CON}, 2 . \mathrm{DM}, 3 . \mathrm{DM}+\mathrm{L}, 4$. DM+H, 5. DM+GB.

varies depending on the conditions of the study. Pancreatic $\beta$ cell damage in this animal model was only partial. Whereas in the animal models induced by streptozotosin, the result shows $\beta$ cell necrosis comprehensively ( Szkudelski, 2012; Szkudelski et al., 2013). Failure of blood glucose control in diabetic rats in this study is more due to the reduced sensitivity of target tissue of the animals to insulin responses.

In type 2 diabetes, there is a decrease in the number of $\beta$ cells. Reduction in the number of $\beta$ cells is caused by glucolipotoxicity and amyloid deposits which trigger oxidative stress and $\beta$ cell apoptosis. Similarly, increasing insulin secretion continuously on the rats to adaptate and tolerate the organ insensitivity will lead to an exhausted condition of $\beta$ cell (Perl et al., 2010). To cope with, the development of knowledge regarding the importance of maintaining $\beta$ cell function has brought implications for the further advances of drugs. The developing drugs should have the capacity in maintaining $\beta$ cells and in improving glucose tolerance. The regeneration of $\beta$ cell is difficult to as well as compensate for its loss since the ability to renew $\beta$ cells itself is limited (Kahn et al., 2014). One of the therapeutic approach to deal with the decrease in $\beta$ cell is to protect and maintain $\beta$ cell function itself so that a decrease in progressive $\beta$ cell can be prevented.

The liver is a primary organ involved in the detoxification process and in the utilization of glucose. It intensively mobilizes and reserves absorbed glucose to maintain the blood glucose level in the normal state (Stadler et al., 2003). Histopathological results of the liver tissue showed that there were morphological changes in the liver of diabetic rats. Conditions such as vacuolization, polymorphonuclear, sinusoid dilatation, and necrosis in the midzonal area are the kind of hepatocyte reactions in overcoming various conditions due to hyperglycemia. MKE administration on the rates improves their liver histopathological changes, like being lighter, so that it supports the hepatoprotective effect of MKE in hyperglycemia. Aligned with this study, the hepatoprotective effect of M. koenigii extract have been reported (Desai et al., 2012; Sathaye et al., 2011).

\section{CONCLUSION}

The study estimated the expression of proinflammatory cytokines level in STZ-NA-induced diabetic rats and investigated the effect of ethanolic $M$. koenigii extract in the amelioration of the inflammation state in hyperglycemic rats. The active compound of the leaves could be used for their antihyperglycemic effects. Besides, the antihyperglycemic effect of MKE resulted from a modulation pro-inflammation cytokines and protective effect on the liver and pancreas of hyperglycemic rats.

\section{ACKNOWLEDGMENT}

The authors would like to thank the Directorate Research and Community Services, Universitas Indonesia, Indonesia for providing financial support.

\section{ABBREVIATIONS}

$\mathrm{PKC}$, protein kinase $\mathrm{C}$; AMPK, 5' adenosine monophosphate-activated protein kinase; $\mathrm{PP} 2 \mathrm{~A}$, protein phosphatase 2A; IKK, IкB kinase; p-JNK, phospho-Jun N-terminal kinase; SOCS, Suppressor of cytokine signaling; TNF- $\alpha$, tumor necrosis factor- $\alpha$; IL- $1 \beta$, interleukin-1 $\beta$; ROS, reactive oxygen species; AGE-RAGE, Advanced glycation end product-receptor 
advanced glycation end product; NF-kB, nuclear factor kappa-B; PCR, polymerase chain reaction; LSD, least significant difference; GC-MS, gas chromatography mass spectrometry; NO, nitric oxide; IRS, insulin receptor substrate

\section{CONFLICT OF INTEREST}

The authors declare that there is no conflicts of interest.

\section{FINANCIAL SUPPORT}

The authors thank the Directorate Research and Community Services, Universitas Indonesia, Indonesia for providing financial support.

\section{REFERENCES}

Bhat AH, Dar KB, Zargar MA, Masood A, Ganie SA, Res D. Modulation of oxidative stress and hyperglycemia by Rheum spiciformis in alloxan induced diabetic rats and characterization of isolated compound. Drug Res 2019; 69(4):218-26.

Birari R, Javia V, Bhutani KK. Antiobesity and lipid lowering effects of Murraya koenigii (L.) Spreng leaves extracts and mahanimbine on high fat diet induced obese rats. Fitoterapia 2010;81(8):1129-33.

Chatterjee S, Khunti K, Davies MJ. Type 2 diabetes. Lancet 2017; 389(10085):2239-51; doi:10.1016/S0140-6736(17)30058-2

de Luca C, Olefsky JM. Inflammation and insulin resistance. FEBS Lett 2008; 582(1):97-105.

Defronzo RA. From the triumvirate to the ominous octet: a new paradigm for the treatment of type 2 diabetes mellitus. Diabetes 2009; 58(4):773-95

DeFronzo RA. Pathogenesis of type 2 diabetes mellitus. Med Clin North Am 2004; 88(4):787-835.

Desai SN, Patel DK, Devkar RV, Patel PV, Ramachandran AV. Hepatoprotective potential of polyphenol rich extract of Murraya koenigii L.: an in vivo study. Food Chem Toxicol 2012; 50(2):310-4.

Desmet VJ. Liver tissue examination, 2003; 39:43-9; doi:10.1016/S0168-8278(03)00138-7

Fernández-Real JM, Pickup JC. Innate immunity, insulin resistance and type 2 diabetes. Trends Endocrinol Metab 2008; 19(1):10-6; doi:10.1016/j.tem.2007.10.004

Franckhauser S, Elias I, Rotter Sopasakis V, Ferré T, Nagaev I, Andersson CX, Agudo J, Ruberte J, Bosch F, Smith U. Overexpression of IL6 leads to hyperinsulinaemia, liver inflammation and reduced body weight in mice. Diabetologia, 2008; 51(7):1306-16.

Grover JK, Yadav S, Vats V. Medicinal plants of India with antidiabetic potential. J Ethnopharmacol, 2002; 81(1):81-100.

Handral HK, Pandith A, Shruthi SD. A review on Murraya koenigii: multipotential medicinal plant. Asian J Pharm Clin Res, 2012; 5(suppl 4):5-14; doi:10.20959/wjpps20168-7309

Husna F, Suyatna FD, Arozal W, Poerwaningsih EH. Anti-Diabetic Potential of Murraya koenigii (L.) and its antioxidant capacity in nicotinamidestreptozotocin induced diabetic rats. Drug Res (Stuttg), 2018; 68(11):631-6.

Holman RR, Paul SK, Bethel MA, Matthews DR, Neil HAW. 10 -Year follow-up of intensive glucose control in type 2 diabetes. N Eng J Med, 2008; 359:1577-89.

Ibrahim FA, Usman LA, Akolade JO, Idowu OA, Abdulazeez AT, Amuzat AO. Antidiabetic potentials of Citrus aurantifolia leaf essential oil. Drug Res (Stuttg), 2018; 10(1); doi:10.1289/image.ehp.v119.i03

IDF. IDF Diabetes atlas. 7th edition, International Diabetes Federation, Brussel, Belgium, pp 1-163, 2015.

Kahn SE, Cooper ME, Del Prato S. Pathophysiology and treatment of type 2 diabetes: Perspectives on the past, present, and future. Lancet, 2014; 383(9922):1068-83; doi:10.1016/S0140-6736(13)62154-6

Kalupahana NS, Moustaid-Moussa N, Claycombe KJ. Immunity as a link between obesity and insulin resistance. Mol Aspects Med 2012; 33(1):26-34. doi:10.1016/j.mam.2011.10.011
Kavishankar GB, Lakshmidevi N. Anti-diabetic effect of a novel $\mathrm{N}$-Trisaccharide isolated from Cucumis prophetarum on streptozotocinnicotinamide induced type 2 diabetic rats. Phytomedicine, 2014; 21(5):62430. doi:10.1016/j.phymed.2013.12.002

Kementerian Kesehatan RI. Formularium obat herbal asli Indonesia, vol. 1, 2011.

Kesari AN, Gupta RK, Watal G. Hypoglycemic effects of Murraya koenigii on normal and alloxan-diabetic rabbits. J Ethnopharmacol, 2005; 97(2):247-51.

Kesari AN, Kesari S, Singh SK, Gupta RK, Watal G. Studies on the glycemic and lipidemic effect of Murraya koenigii in experimental animals. J Ethnopharmacol, 2007; 112(2):305-11; doi:10.1016/j. jep.2007.03.023

Lin HV, Accili D. Hormonal regulation of hepatic glucose production in health and disease. Cell Metab 2011; 14(1):9-19; doi:10.1016/j.cmet.2011.06.003

Luis-Rodríguez D. Pathophysiological role and therapeutic implications of inflammation in diabetic nephropathy. World J Diabetes, 2012; 3(1):7. Available via http://www.wjgnet.com/1948-9358/full/v3/i1/7.htm

Majaw S, Challam SK, Syiem D. Effect of Potentilla Fulgens L. on selected enzyme activities and altered tissue morphology in diabetic mice. J Morphol Sci, 2018; 35:153-60.

Moore MC, Coate KC, Winnick JJ, An Z, Cherrington AD. Regulation of hepatic glucose uptake and. Adv Nutr, 2012;3(April):286-94.

Ningappa MB, Dinesha R, Srinivas L. Antioxidant and free radical scavenging activities of polyphenol-enriched curry leaf (Murraya koenigii L.) extracts. Food Chem, 2008; 106(2):720-8; doi:10.1016/j. foodchem.2007.06.057

Paul S, Bandyopadhyay TK, Bhattacharyya A. Immunomodulatory effect of leaf extract of Murraya koenigii in diabetic mice. Immunopharmacol Immunotoxicol, 2011; 33(4):691-9.

Perl SY, Kushner JA, Buchholz BA, Meeker AK, Stein GM, Hsieh M, Kirby M, Pechhold S, Liu EH, Harlan DM, Tisdale JF. Significant human $\beta$-cell turnover is limited to the first three decades of life as determined by in vivo thymidine analog incorporation and radiocarbon dating. J Clin Endocrinol Metab, 2010; 95(10):234-9; doi:10.1210/jc.20100932

Pickup JC. Inflammation and activated innate immunity in the pathogenesis of type 2 diabetes. Diabetes Care, 2004; 27(3):813-23. Available via http://www.ncbi.nlm.nih.gov/pubmed/14988310.

Rajendiran D, Packirisamy S, Gunasekaran K. A review on role of antioxidants in diabetes.Asian J Pharm Clin Res, 2018; 11(2):48-53.

Riset Kesehatan Dasar. RISKESDAS. Badan Penelitian dan Pengembangan Kesehatan. Kementrian Kesehatan RI, Jakarta, Indonesia, pp 87-100, 2013 .

Risk NCD, Collaboration F. Worldwide trends in diabetes since 1980: a pooled analysis of 751 population-based studies with 4.4 million participants. Lancet, 2016; 387(10027):1513-30; doi:10.1016/S01406736(16)00618-8

Samanta SK, Kandimalla R, Gogoi B, Dutta KN, Choudhury P, Deb PK, Dev R, Pal BC, Talukdar NC. Phytochemical portfolio and anticancer activity of Murraya koenigii and its primary active component, mahanine. Pharmacol Res, 2018; 129:227-36.

Sathaye S, Bagul Y, Gupta S, Kaur H, Redkar R. Hepatoprotective effects of aqueous leaf extract and crude isolates of Murraya koenigii against in vitro ethanol-induced hepatotoxicity model. Exp Toxicol Pathol, 2011; 63(6):587-91; doi:10.1016/j.etp.2010.04.012

Shah AS, Wakade AS, Juvekar AR. Immunomodulatory activity of methanolic extract of Murraya koenigii (L) Spreng. leaves. Indian J Exp Biol, 2008; 46(7):505-9.

Stadler K, Jenei V, Von Bölcsházy G, Somogyi A, Jakus J. Increased nitric oxide levels as an early sign of premature aging in diabetes. Free Radic Biol Med, 2003; 35(10):1240-51.

Stumvoll M, Goldstein BJ, van Haeften TW. Type 2 diabetes: principles of pathogenesis and therapy. Lancet, 2005; 365(9467):1333-46. Available via http://www.ncbi.nlm.nih.gov/pubmed/15823385. 
Szkudelski T. Streptozotocin-nicotinamide-induced diabetes in the rat. Characteristics of the experimental model. Exp Biol Med, 2012; 237(5):481-90.

Szkudelski T, Zywert A, Szkudelska K. Metabolic disturbances and defects in insulin secretion in rats with streptozotocin-nicotinamideinduced diabetes. Physiol Res, 2013; 62(6):663-70.

Tahrani AA, Bailey CJ, Del Prato S, Barnett AH. Management of type 2 diabetes: new and future developments in treatment. Lancet, 2011; 378(9786):182-97.

\section{How to cite this article:}

Husna F, Suyatna FD, Arozal W, Purwaningsih EH, Sani Y. Restoration of pro-inflammatory cytokines and histopathological of pancreas and liver change in hyperglycemia rats by Murraya koenigii leaves extract. J Appl Pharm Sci, 2020; 10(1):008-015. 